\title{
How does the physiological activity and growth of tomato plants react to the use of a soil-mineral compound?
}

\section{¿Cómo reacciona la actividad fisiológica y el crecimiento de las plantas de tomate al uso de un compuesto suelo-mineral?}

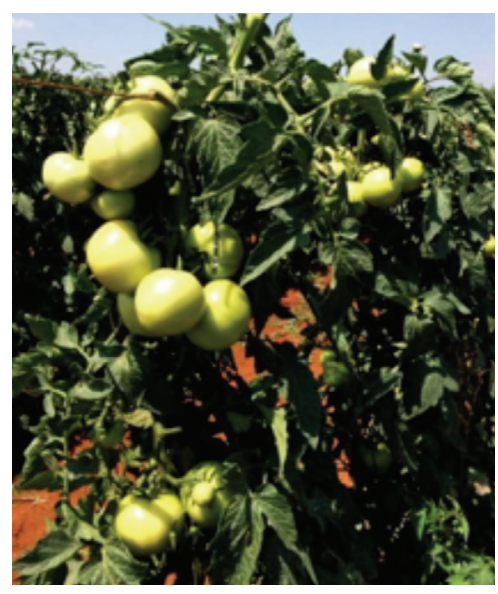

ISABELLA SABRINA PEREIRA ${ }^{1,3}$

EVANDRO BINOTTO FAGAN ${ }^{2}$

ELLEN MAYARA ALVES CABRAL'1

DANIELE CRISTINA FONTANA ${ }^{1}$

RENAN CALDAS UMBURANAS ${ }^{1}$

LUÍS HENRIOUE SOARES ${ }^{2}$

\begin{abstract}
The tomato crop has a high productive potential that can be depleted by biotic and abiotic stresses. Increased plant resilience to stress conditions has been reported with foliar applications of soil-mineral compounds; however, it is necessary to better understand how plants react to the use of this compound. Thus, this study evaluated the effect of foliar applications of a soil-mineral compound on the physiological and growth attributes of tomato plants. This experiment was carried out in Lagoa Formosa/MG during 2016. Different rates of the soil-mineral compound were used during the crop cycle, forming four distinct managements. The management consisted of different doses of the mineral compound in four stages after transplanting the tomato seedlings. The experiment design used randomized blocks. The following physiological evaluations were performed: total soluble protein, hydrogen peroxide, nitrate reductase enzyme activity, urease, superoxide dismutase (SOD), peroxidase, phenylalanine ammonia lyase, and lipid peroxidation (LP). The growth assessments were plant biomass and yield. Foliar applications of the soil-mineral compound increased the activity of the SOD enzyme by 4.17 and $6.25 \%$. The use of the soil-mineral compound also increased the LP activity and reduced the antioxidant enzyme activity. The foliar application of the soil-mineral compost at doses of $0.5,0.750,1.0$ and $1.0 \mathrm{~kg} \mathrm{ha}^{-1}$ at 15, 25, 40 and 60 days after transplanting, respectively, increased the yield of the table tomatoes by $20 \%$.
\end{abstract}

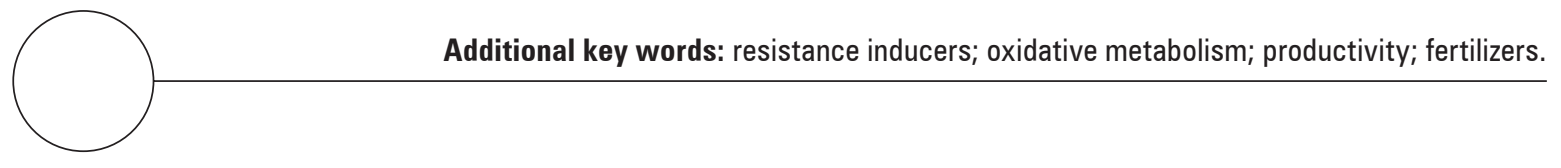

1 University of São Paulo, "Luiz de Queiroz" College of Agriculture, Department of Plant Production, Piracicaba (Brazil). ORCID Pereira, I.S.: 0000-0001-6444-7504; ORCID Cabral, EM.A.: 0000-0002-9751-0642; ORCID Fontana, D.C.: 0000-0003-4285-6299; Umburanas, R.C.: 0000-0002-4112-3598

2 Centro Universitário Patos de Minas, Department of Plant Production, Patos de Minas (Brazil). ORCID Fagan, E.B.: 0000-0002-0281-5874; ORCID Soares, L.H.: 0000-0002-0737-3745

3 Corresponding author. isabella.sabrina.p@hotmail.com 


\section{RESUMEN}

El cultivo de tomate presenta un alto potencial productivo pero puede afectarse debido al estrés biótico y abiótico. Se ha informado un aumento de la resistencia de la planta a las condiciones de estrés con la aplicación foliar de compuestos minerales del suelo, sin embargo, aún es necesario comprender mejor cómo reacciona la planta al uso de este compuesto. Por lo tanto, este estudio evaluó el efecto de la aplicación foliar del compuesto mineral del suelo sobre los atributos fisiológicos y de crecimiento de las plantas de tomate. Este experimento se llevó a cabo en Lagoa Formosa / MG durante 2016. Se usaron diferentes tasas del compuesto mineral del suelo durante el ciclo del cultivo, lo que constituye cuatro manejos distintos. El manejo consistió en diferentes dosis del compuesto mineral en cuatro etapas después del trasplante de las plántulas de tomate. El diseño experimental utilizado fue de bloques al azar. Se realizaron las siguientes evaluaciones fisiológicas: proteína soluble total, peróxido de hidrógeno, actividad de la enzima nitrato reductasa, ureasa, superóxido dismutasa (SOD), peroxidasa, fenilalanina amoniaco liasa y peroxidación lipídica (LP). Las evaluaciones de crecimiento fueron biomasa vegetal y rendimiento. La aplicación foliar del compuesto mineral del suelo aumentó la actividad de la enzima SOD en 4,17 y 6,25\%. El uso del compuesto mineral del suelo también aumentó la actividad de LP y redujo la actividad de las enzimas antioxidantes. La aplicación foliar de compost mineral del suelo a dosis de 0,5; 0,750; 1,0 y $1.0 \mathrm{~kg} \mathrm{ha}^{-1}$ a los 15, 25, 40 y 60 días después del trasplante, respectivamente, aumentó el rendimiento de tomates de mesa al $20 \%$.

Palabras clave adicionales: inductores de resistencia; metabolismo oxidativo; productividad; fertilizantes.

Received for publication: 19-04-2019 Accepted for publication: 31-07-2019

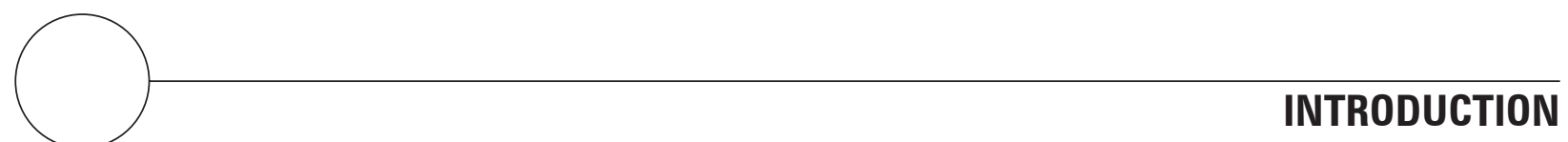

The tomato (Solanum lycopersicum L.) is one of the most consumed vegetables globally, mainly because of its high nutritional value and antioxidant potential (Du et al., 2017). Overall tomato production increased from 27.6 million tons in 1960 to 177 million tons in 2016 (FAOSTAT, 2016). In Brazil, table tomato cultivation stands out because of its socioeconomic importance, as it generates jobs, improving the income of rural workers and growers (Silva et al., 2013). Many factors can lead to a reduction in crop productivity, affecting the quality of the final product, which include problems caused by pests and diseases (Zaidi et al., 2018).

Disease management has become a challenge in agriculture as it requires pesticides, often with high toxicity (Carrascosa et al., 2015). Chemical pesticides, particularly soil fumigants, have been severely restricted in recent decades because of the environmental consequences (Van Bruggen and Finckh, 2016), the residual effects on soil and the long period necessary for degradation. In addition, the use of pesticides in the environment impacts human health, and resistance is acquired by pathogens for the chemical groups. The use of pesticides should be minimized and rationalized to promote more sustainable agriculture (Lamichhane et al., 2015).

Phytosanitary management needs to be improved to minimize or mitigate its impact on the environment (Dayan et al., 2009). Plants have mechanisms to respond to different types of stress, whether abiotic (Shah et al., 2014) or biotic (Shah and Zeier, 2013). These natural defense mechanisms remain inactive or latent until activated after exposure and/or contact with inducing agents (Mandal, 2010).

The defense mechanisms of a plant are genetically controlled, depending on the expression after contact with the host. So, plants can activate the defense mechanism in several ways, including through oxidative activities (Teixeira et al., 2017; Xue and Yi, 2017), enzymes involved in the phenylpropanoid route (Sangeetha and Sarada, 2015), and enzymes involved in lipid peroxidation, among other forms. The use of resistance-inducing products for different crops is increasing, for example on vine (Xue and Yi, 2017), wheat (Moya-Elizondo and Jacobsen, 2016), pepper (Siddiqui and Meon, 2009), and peach (Jiao et al., 2018), mainly. 
When plants recognize the resistance inducers applied, the intracellular signal transduction pathways are activated (Shah et al., 2014). Perception occurs when the molecules of the inducing agent bind to receptor molecules that are probably located in the plasma membrane of the plant cell; this reaction triggers the activation of various defense mechanisms, culminating in protection against pathogens (Graham and Myers, 2011). These inductions alter the physiology of the plant and can interfere directly with productivity.

Application of resistance inductors that have Silicon $(\mathrm{Si})$ is a potentially sustainable option to improve biotic and abiotic stresses in several plants ( $\mathrm{Zhu}$ and Gong, 2014; Liang et al., 2015; Cooke and Leishman, 2016; Etesami, 2018).

Despite the importance of the use of these products, there are few studies on resistance inductors based on silicon oxide and aluminum in the tomato to table culture. One source of these nutrients available to growers is through soil-mineral compost. Thus, this study evaluated the effect of foliar applications of a soil-mineral compound on the physiological and growth attributes of tomato plants.

\section{MATERIAL AND METHODS}

This experiment was conducted in the 2016 growing season in the commercial area of Lagoa Formosa, Minas Gerais, Brazil (18³0'01.6" S and 46 $30^{\prime} 48.2^{\prime \prime}$ $\mathrm{W})$ in the first crop of the year. The cultivar "Dominador" was used, which has an indeterminate growth habit, high vigor, average cycle duration of $120 \mathrm{~d}$ and fruits with an aptitude for salads. The seedlings were produced in trays and transplanted to the field when they had two leaves, $28 \mathrm{~d}$ after sowing.

Cultural management including fungicides, insecticides and herbicides was carried out in all treatments. Each plot was composed of five rows, with a $6 \mathrm{~m}$ length, $2 \mathrm{~m}$ row spacing, and $0.6 \mathrm{~m}$ between plants. The useful area of each plot consisted of the three central lines, discarding $0.5 \mathrm{~m}$ at each border. The plants were irrigated with a central pivot and received fertirrigation according to the nutritional needs of the crop.

The experiment design used a randomized block with four treatments and five replications. The treatments consisted of four management types of the soil-mineral compound during the crop cycle: management 1 was the control; management 2 consisted of foliar applications at the dose of $0.75 \mathrm{~kg} \mathrm{ha}^{-1}$ per application at 15, 25, 40 and 60 days after transplanting (DAT); management 3 consisted of foliar applications of $0.5 \mathrm{~kg} \mathrm{ha}^{-1}$ at 15 DAT, $0.750 \mathrm{~kg} \mathrm{ha}^{-1}$ at 25 DAT, $1.0 \mathrm{~kg} \mathrm{ha}^{-1}$ at 40 DAT, and again at 60 DAT; and management 4 consisted of foliar applications of 1.0 $\mathrm{kg} \mathrm{ha}^{-1}$ per application at 15, 25, and 40 DAT.

The soil-mineral compound was a fine, balanced powder, prepared by milling, micronization and standardization of special clays that are commercially distributed in Brazil. The soil-mineral compound was a fine powder composed of $\mathrm{Al}_{2} \mathrm{O}_{3}(20.6 \%), \mathrm{SiO}_{2}(17.4 \%)$, $\mathrm{S}(9.8 \%), \mathrm{CaO}(1.3 \%), \mathrm{TiO}_{2}(0.34 \%), \mathrm{MgO}(0.18 \%)$, $\mathrm{Fe}_{2} \mathrm{O}_{3}(0.16 \%)$, and $\mathrm{P}_{2} \mathrm{O}_{5}(0.10)$. The doses were as indicated in the commercial product (Rocksil ${ }^{\circledR}$ ).

The foliar applications were done with costal spraying with a $\mathrm{CO}_{2}$ injection. The bar contained a fantype nozzle, with a constant pressure of 2.0 bar.

\section{Biochemical evaluations}

Leaf samples for the nitrate reductase determinations were performed at 8, 26, 40, 47 and 73 DAT, and, for the other analyses, they were taken only at 73 DAT. Completely expanded leaves were collected from the middle third of the plants.

The activity of the enzymes nitrate reductase, urease, lipid peroxidation, peroxidase enzymes, superoxide dismutase, phenylalanine ammonia-lyase, hydrogen peroxide, and total proteins were determined.

The NR analysis was performed according to the method proposed by Mulder et al. (1959). The urease was evaluated throughout extraction, and the analysis of the plant material was done according to the methodology adapted from Hogan et al. (1983).

Samples of $200 \mathrm{mg}$ of fresh biomass of leaves were macerated with $4.0 \mathrm{~mL}$ of $0.1 \mathrm{~mol} \mathrm{~L}^{-1}$ potassium phosphate buffer $\mathrm{pH}$ 6.8. Then, the samples were transferred to Eppendorf flasks and centrifuged at 10,000 rpm for $30 \mathrm{~min}$ at $4^{\circ} \mathrm{C}$ (Kar and Mishra, 1976). Then, the samples were stored at $-20^{\circ} \mathrm{C}$ until determination of the total protein content of the leaf (Bradford, 1976), superoxide dismutase activity (SOD) (Beuchamp and Fridovich, 1971), peroxidase activity (POD) (Teisseire and Guy, 2000), and phenylalanine 
ammonia-lyase activity (PAL) (Umesha, 2006). With the fresh leaf biomass the hydrogen peroxide content $\left(\mathrm{H}_{2} \mathrm{O}_{2}\right)$ (Alexieva et al., 2001) and lipid peroxidation (LP) (Heath and Packer, 1968) were also evaluated.

\section{Biomass attributes}

One plant per replicate was harvested at 47 and 83 DAT for determination of the root, stem and leaf biomass. The samples were dried in a forced-air oven at $65^{\circ} \mathrm{C}$ for $48 \mathrm{~h}$ before the determination of the dry biomass. Productivity harvests were also performed at $73,81,92,102,110,119,124,130$ DAT.

\section{Statistical analysis}

The data were evaluated for normality and homogeneity using Levene and Shapiro-Wilk tests, both at the 5\% significance level. A variance analysis was performed, and, when significant, the Tukey test was applied at the $5 \%$ level of significance. For some analyses, regression analysis was also performed. The analyses were performed using statistical software Genes (Cruz, 2013).

\section{RESULTS AND DISCUSSION}

For the nitrate reductase variable, the variance analysis presented significance only for the management; there was no effect from the harvesting times or interaction. The other attributes of nitrogen metabolism and the activity of antioxidant enzymes had no effect from the management. There was a difference in the productivity attributes.

The nitrate reductase enzyme did not present a significant difference during the evaluation periods although some management showed a tendency for increasing (Fig. 1). The nitrate reductase enzyme acts on nitrogen assimilation in plants and reduces nitrate to nitrite through $\mathrm{NADPH}$ (nicotinamide adenine dinucleotide phosphate hydrogen) energy. Thus, the increase in this enzyme activity contributes to the increase of the assimilation of nitrogen $(\mathrm{N})$ and the growth and development of the plant (Taiz et al., 2016).

Resistance induction represents an extra energy expenditure for plant defense and reduces nitrate reductase metabolism and consequently plant growth.

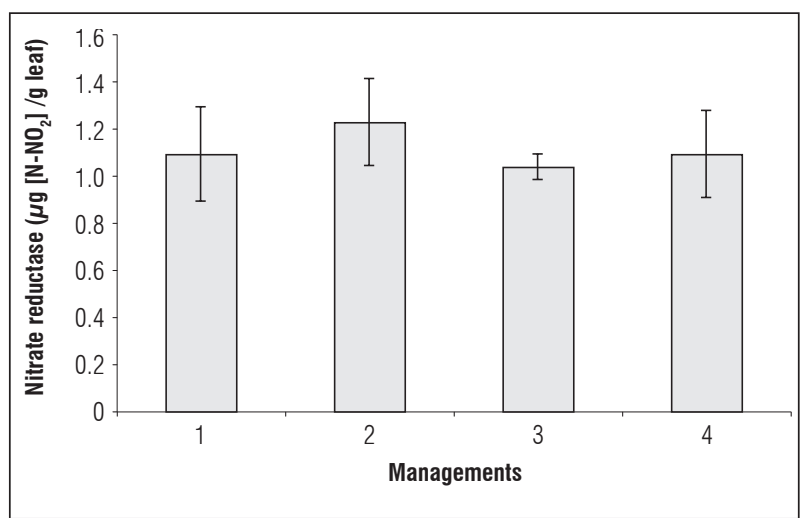

Figure 1. Activity of the enzyme nitrate reductase when submitted to different managements for foliar applications of the soil-mineral compound. Nitrate reductase $\left(\mu \mathrm{g} \mathrm{N}-\mathrm{NO}_{2} / \mathrm{g}\right.$ leaf). The vertical bars indicate \pm standard error.

Thus, we verified that the foliar applications of the soil-mineral compound may not have activated resistance mechanisms related to the nitrogen metabolism enzymes.

According to Lawlor (2002), the role of nitrogen in the production of dry phytomass and, consequently, remobilization to reserve organs is directly related to photosynthesis. Photon energy is converted into chemical energy and stored in ATP (Adenosine triphosphate) and secondary metabolites, primarily $\mathrm{NADH}$, which is used in the synthesis of carbon and nitrogen assimilates, particularly amino acids (Lawlor, 2002).

It was found that the activity of nitrate reductase reduces during harvests, more accentuated after flowering. We hypothesize that the fruiting drain competes for the $\mathrm{N}$ present in the plant, which explains this reduction in enzyme activity.

The protein content and the activity of the urease enzyme did not differ between the management types; however, it was noted that treatments 2,3 and 4 increased the total protein content (Fig. 2A).

The quantification of the protein content in the leaf during the reproductive growth evidences the redistribution of amino acids from leaves to reproductive growth. A higher protein content in the leaves may be an indicator of greater assimilation of atmospheric $\mathrm{CO}_{2}$ because the main enzyme of photosynthesis is composed of $\mathrm{N}$, the ribulose-1.5-bisphosphate carboxylase/oxygenase (Rubisco) (Taiz et al., 2016). 

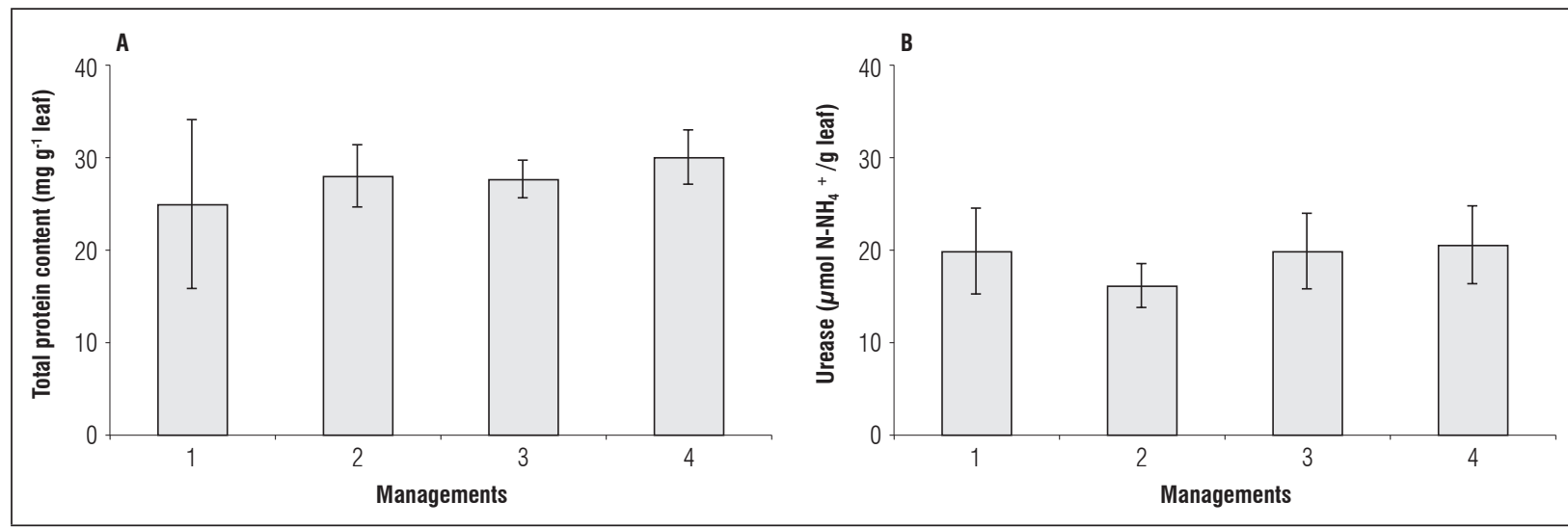

Figure 2. Protein content (A) and urease enzyme activity (B) in tomato leaves at 73 DAT when submitted to different management types for foliar applications of the soil-mineral compound. The vertical bars indicate \pm standard error.

\section{Oxidative metabolism}

The managements 2, 3 and 4 presented higher levels of hydrogen peroxide than management 1 (control), without significant differences (Fig. 3A). Management 4 presented, on average, values of hydrogen peroxide production that were approximately $56 \%$ higher than treatment 1 (control), which demonstrated that the resistance inducer activated the oxidative metabolism in some signal transduction pathways in the plant tissue.

The increase of this free radical indicates that the defense signaling of the plants probably activated genes related to pathogenesis. Thus, the increase in the synthesis of hydrogen peroxide does not always result in negative effects in plants, such as destruction of membranes, because this molecule can function as a signal agent in plants, which includes responses to pathogen elicitors, stomatal closure, acquired systemic resistance, and programmed cell death (Chen and Gallie, 2005).

For the enzyme POD, there was a positive trend in managements 2, 3 and 4 , without statistical significance (Fig. 3B). The increase in the activity of the $\mathrm{POD}$ enzyme as well as the increase in $\mathrm{H}_{2} \mathrm{O}_{2}$ content was a protective measure to degrade the reactive oxygen species (ROS) in the plants (Barbosa et al., 2014). PODs are related to the synthesis of lignin and suberin, which increase the hardness of tissues and the production of quinones and active oxygen, which have antibiotic activities (Stout et al., 1994).
The activity of the SOD enzyme was reduced in managements 3, 4 and 2, in relation to treatment 1 (control) (Fig. 3C). This enzyme is responsible for the degradation of superoxide ERO in hydrogen peroxide, so it is later degraded by CAT and POD enzymes (Mittler, 2002). An increased SOD and POD activity is directly related to plant tolerance to environmental stresses, such as saline stress (Koca et al., 2007). However, when the activity of the enzyme is saturated before reaching the maximum concentration of reactive oxygen species, lipid peroxidation may occur.

The activity of the PAL had a different behavior (Fig. 3D). This enzyme is responsible for catalyzing the conversion of phenylalanine to trans cinnamic acid, the first step for the biosynthesis of phenylpropanoids. This compound is the basis for the synthesis pathway of secondary metabolites that exhibit antioxidant activity, such as flavonoids and tannins (Dias et al., 2015). A different behavior can be explained by a different route of action for defending plants against stress. Alternative products, such as chitosan and plant extracts, may increase the activity of phenylalanine-ammonia-lyase (PAL) (Lorencetti et al., 2015).

The levels of lipid peroxidation were similar among all treatments (Fig. 3E). Lipid peroxidation is used as a basis to measure the damage caused by the action of reactive oxygen species on the unsaturated lipids of cell membranes. This leads to membrane destruction, failure of cellular mechanisms and, in extreme cases, cell death (Lima and Abdalla, 2001). Therefore, 

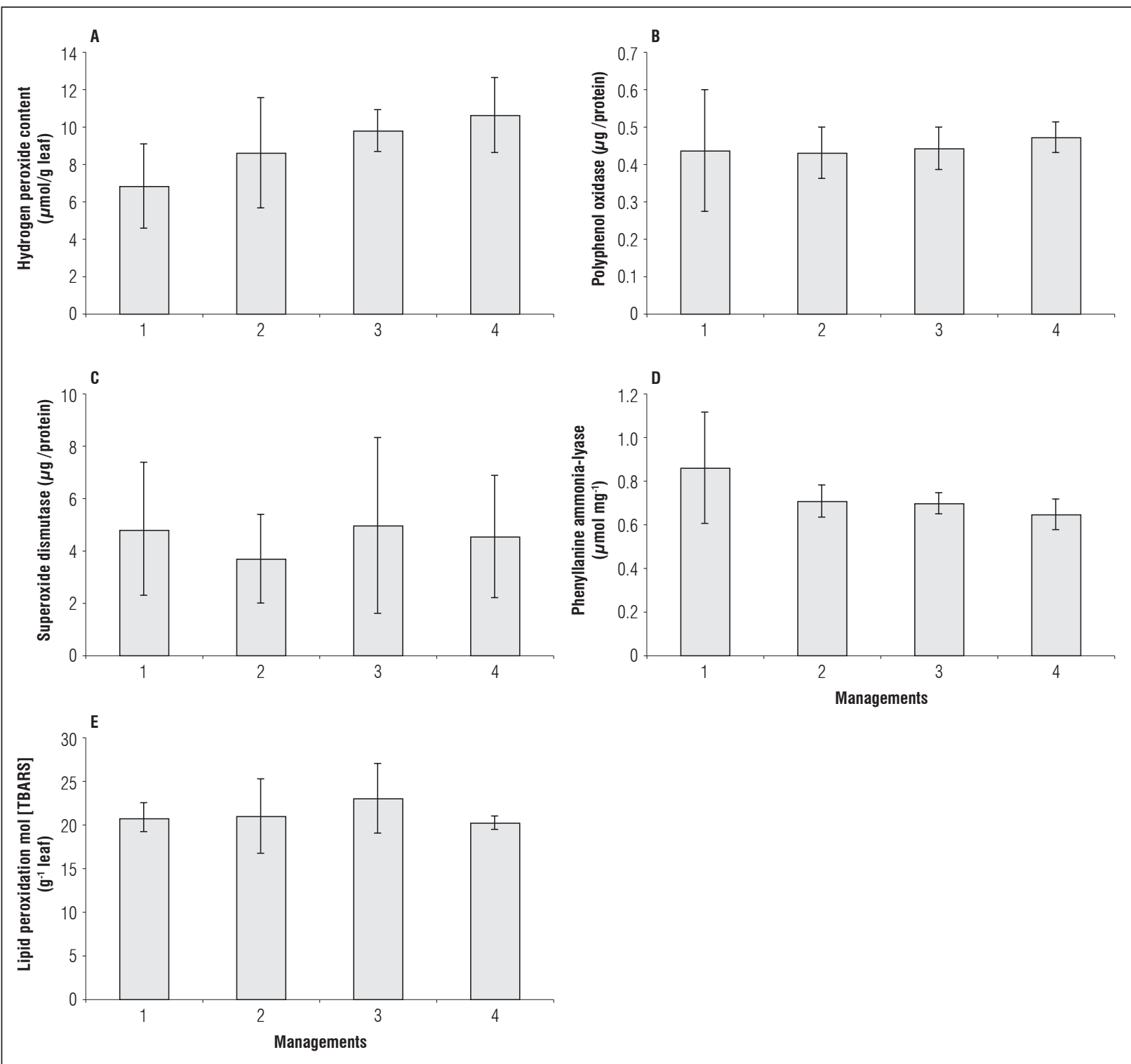

Figure 3. Hydrogen peroxide content (A), polyphenol oxidase activity (B), superoxide dismutase $\mu^{-1}$ (C), phenylalanine ammonia-lyase (D), and lipid peroxidation (E) of tomato leaves at 73 DAT, when submitted to different management types for foliar applications of the soil-mineral compound. The vertical bars indicate \pm standard error.

because there was no difference between the treatments and the control, there was no cellular damage from the foliar application of the soil-mineral compound.

Silicon increases the synthesis of phenolic compounds in plants and increases the activity of the following enzymes: polyphenol oxidase (PPO), peroxidases (POD) and phenylalanine ammonia-lyase (PAL) (Gomes et al., 2005). As a consequence, it tends to reduce the rate of pathogen growth and the incidence of pest insects. The application of Si increased the accumulation of phenolic compounds in walls of epidermal cells of Triticum aestivum, and consequently, increased the resistance of plants infected by Blumeria graminis f. sp. tritici (Bélanger et al., 2003).

A PPO plays an important role in plants since it provides resistance to attack from pathogens and diseases. It has also been reported that PPO may exert a direct relationship with photosynthesis since it assists in the maintenance of system homeostasis 
(Boeckx et al., 2015). This enzyme performs the oxidation of diphenol in quinone, a beneficial compound for the photosystem. In addition, during this process, $\mathrm{PPO}$ removes excess $\mathrm{O}_{2}$ from the system, avoiding the possible formation of superoxide radicals (Boeckx et al., 2015).
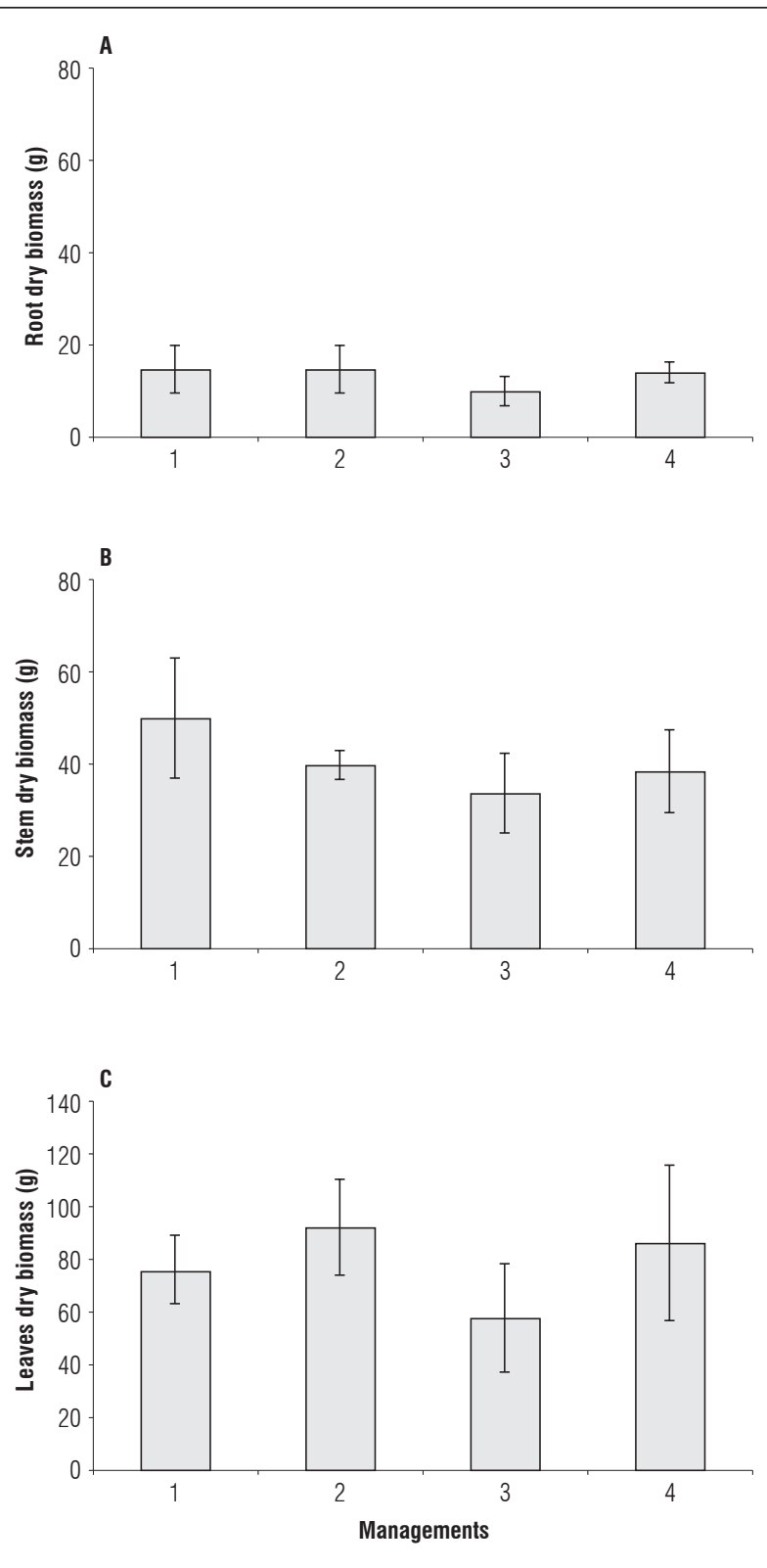

Figure 4. Root (A), stem (B), and leaf (C) biomass of tomato plants when submitted to different management types for foliar applications of the soil-mineral compound. The vertical bars indicate \pm standard error.
Although the foliar applied soil-mineral compound had Si, no change in the activity of SOD and PAL enzymes was observed. The interaction of Si with these enzymes is probably more complex and depends on other factors, such as dose, culture, form of application, and interaction with other nutrients in the application, among other factors, which needs more studies to be better understood.

\section{Biomass attributes}

About $95 \%$ of the dry mass accumulated by plants during their cycle is derived from the photosynthetic activity, and the rest comes from the soil (Benincasa, 2004). The root dry and stem dry biomass did not differ between the management types (Fig. 4AB). There was a trend for a higher dry leaf biomass in management 4, without significant differences (Fig. 4C).

$\mathrm{Si}$, after being absorbed, is translocated and deposited just below the cuticle, forming a double layer of silicon-cuticle. This contributes to protection from abiotic stresses, such as: elemental toxicity, salinity, and frost, among others; as well as protection from biotic stresses, such as pests and diseases (Ranganathan et al., 2006). The accumulation of Si makes leaves more upright and rigid and increases the interception of light and, consequently, photosynthetic efficiency (Gonçalves, 2009).

\section{Productivity}

All treatments with foliar applications of the soilmineral compost increased yield per plant and yield. The highest production per plant and productivity were obtained in management 3 , with $3.11 \mathrm{~kg} /$ plant and $31,152 \mathrm{~kg} \mathrm{ha}^{-1}$, respectively (Fig. 5, A and B). The use of the soil mineral compost increased tomato yield by $20 \%$ in management 3 , a good option for increasing crop productivity.

$\mathrm{Si}$, applied in the form of aluminum silicate on vines (Vitis vinifera), contributes to the control of mildew (Plasmopara viticola) (Gomes et al., 2011). The use of a soil-mineral compost in guava (Psidium guajava) contributes to the control of anthracnose (Colletotrichum gloeosporioides) and reduced the diameter of colletotricum lesions (Colletotrichum gloesporioides) in fruits (Gomes et al., 2016). The aluminum oxide $\left(\mathrm{Al}_{2} \mathrm{O}_{3}\right)$, silicon dioxide $\left(\mathrm{SiO}_{2}\right)$ and sulfur $(\mathrm{S})$ present in the soil-mineral compost inhibited in vitro tests on the 

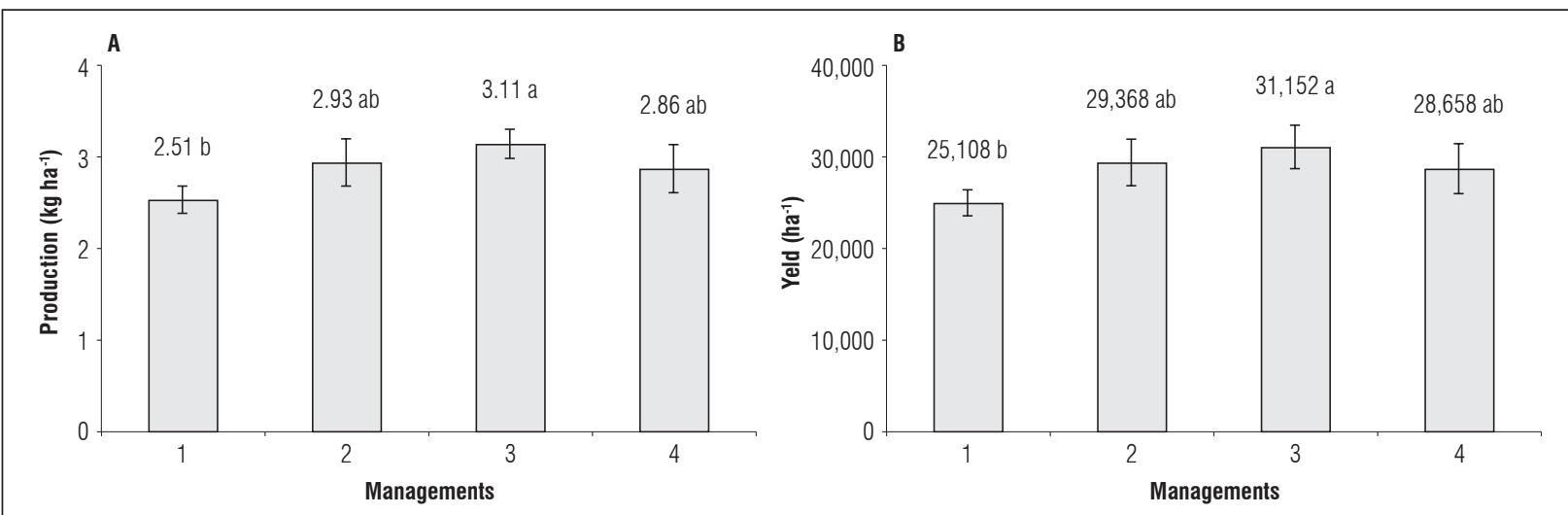

Figure 5. Production per plant (A) and yield (B) of tomato plants when submitted to different management types of foliar applications of the soil-mineral compost. Means with different letters indicate a significant statistical differences according to Tukey test $(P \leq 0.05)(n=5) \pm$ standard error.

mycelial growth of colletotrichum (Colletotrichum gloesporioides) (Gomes et al., 2016).

We hypothesize that foliar applications of aluminum oxides can trigger the production of reactive oxygen species in plants, which stimulates the production of antioxidant enzymes.

Si was identified as a resistance inducer in some monocotyledons, such as rice (Oriza sativa), corn (Zea mays L.) and wheat (Triticum aestivum L.), which actively absorb and accumulate large amounts of silicon (Liang et al., 2015). This was also observed in some dicotyledonous crops, such as cotton (Gossypium hirsutum), soybean (Glycine max (L.) Merr.), and tomato (Solanum lycopersicum L.), and also in some cucurbitaceous species (Liang et al., 2015).

Si can favor the upright position of leaves, indirectly favors photosynthesis, and makes the opening and closing of stomata more efficient (Pereira et al., 2003). The productivity of sugarcane increased with the foliar applications of Si (Elawad et al., 1982). Foliar applications of potassium silicate $\left(\mathrm{K}_{2} \mathrm{SiO}_{3}\right)$ increase the chlorophyll content and growth of strawberry plants (Fragaria $\times$ ananassa) (Wang and Galletta, 1998).

The effectiveness of the application of $\mathrm{Si}$ in the mitigation of stress depends on the species (Mitani and Ma, 2005) and the level of stress suffered by the plant (Hodson et al., 2005). In this experiment, the plants were not subjected to severe stress conditions, which may have contributed to the stress metabolism not responding significantly to the soil-mineral compound treatments. Biochemical and molecular responses using Si occur when the plant is subject to stress conditions (Liang et al., 2015).

Although the treatments with foliar applications did not modify the activity of the evaluated enzymes, the increase in productivity showed that the management types with the compost soil mineral contributed in another way to an increased tomato productivity. We hypothesized that there may have been an increase in proteins, lignins, and efficiency of the photosynthetic activity, but more studies are required for a better understanding.

\section{CONCLUSION}

The foliar applications of the soil-mineral compost at doses of $0.5,0.75,1.0$ and $1.0 \mathrm{~kg} \mathrm{ha}^{-1}$ at $15,25,40$ and 60 DAT, respectively, increased the yield of the table tomatoes.

No effect from the foliar applications of the soil-mineral compound was observed on the enzymes related to stress metabolism as a total protein, hydrogen peroxide, nitrate reductase enzyme activity, urease, superoxide dismutase, peroxidase, phenylalanine ammonia lyase and lipid peroxidation under the conditions of this study.

Conflict of interests: this manuscript was prepared and reviewed with the participation of all authors, who declare that there exists no conflict of interest that puts at risk the validity of the presented results. 


\section{BIBLIOGRAPHIC REFERENCES}

Alexieva, V., I. Sergiev, S. Mapelli, and E. Karanov. 2001. The effect of drought and ultraviolet radiation on growth and stress markers in pea and wheat. Plant Cell Environ. 24(12), 1337-134. Doi: 10.1046/j.1365-3040.2001.00778.x

Barbosa, M.R., M.M.A. Silva, L. Willadino, C. Ulisses, and T.R. Camara. 2014. Geração e desintoxicação enzimática de espécies reativas de oxigênio em plantas. Ciênc. Rural 44(3), 453-460. Doi: 10.1590/ S0103-84782014000300011

Bélanger, R.R., N. Benhamou, and J.G. Menzies. 2003. Cytological evidence of an active role of silicon in wheat resistance to powdery mildew (Blumeria graminis f. sp. tritici). Phytopathology 93(4), 402-412. Doi: 10.1094/PHYTO.2003.93.4.402

Benincasa, M.M.P. 2004. Análise de crescimento de plantas: noções básicas. FUNEP, Jaboticabal, Brazil.

Beuchamp, C.H. and I. Fridovich. 1971. Superoxide dismutase: improved assays and an assay applicable to acrylamide gels. Anal. Biochem. 44(1), 276-287. Doi: 10.1016/0003-2697(71)90370-8

Boeckx, T., A.L. Winters, K.J. Webb, and A.H. Kingston-Smith. 2015. Polyphenol oxidase in leaves; is there any significance to the chloroplastic localization? J. Exp. Bot. 66(12), 3571-3579. Doi: 10.1093/jxb/erv141

Bradford, M.M. 1976. A rapid and sensitive method for the quantification of microgram quantities of protein utilizing the principle of protein-dye binding. Anal. Biochem. 72(1-2), 248-254. Doi: 10.1016/0003-2697(76)90527-3

Carrascosa, M., S. Sanchez-Moreno, and J.L. Alonso-Prados. 2015. Effects of organic and conventional pesticides on plant biomass, nematode diversity and the structure of the soil food web. Nematol. 17(1), 11-26. Doi: 10.1163/15685411-00002849

Chen, Z. and D.R. Gallie. 2005. Increasing tolerance to ozone by elevating foliar ascorbic acid confers greater protection against ozone than increasing avoidance. Plant Physiol. 138(3), 1673-1689. Doi: 10.1104/ pp. 105.062000

Cooke, J. and M.R. Leishman. 2016. Consistent alleviation of abiotic stress with silicone addition: a meta-analysis. Funct. Ecol. 30(8), 1340-1357. Doi: 10.1111/1365-2435.12713

Cruz, C.D. 2013. Genes: a software package for analysis in experimental statistics and quantitative genetics. Acta Sci. Agron. 35(3), 271-276. Doi: 10.4025/actasciagron.v35i3.21251

Dayan, F.E., C.L. Cantrell, and S.O. Duke. 2009. Natural products in crop protection. Bioorg. Med. Chem. 17(12), 4022-342. Doi: 10.1016/j.bmc.2009.01.046
Dias, T., H.C. Mello F.R.R. Alves, R.F. Carvalho, K.S. Carneiro, and C.M. Sousa. 2015. Compostos fenólicos e capacidade antioxidante em frutos de tomateiros mutantes fotomorfogenéticos. Ciênc. Rural 5(45), 782787. Doi: 10.1590/0103-8478cr20140098

Du, Y.D., H.X. Cao, S.Q. Liu, X.B. Gu, and Y.X. Cao. 2017. Response of yield, quality, water and nitrogen use efficiency of tomato to different levels of water and nitrogen under drip irrigation in Northwestern China. J. Integr. Agric. 16(5), 1153-1161. Doi: 10.1016/ S2095-3119(16)61371-0

Elawad, S.H., G.J. Gascho, and J.J. Street. 1982. Response of sugarcane to silicate source and rate: growth and yield. Agron. J. 74(3), 481-484. Doi: 10.2134/agronj19 82.00021962007400030019x

Etesami, H. 2018. Bacterial mediated alleviation of heavy metal stress and decreased accumulation of metals in plant tissues: mechanisms and future prospects. Ecotoxicol. Environ. Saf. 147, 175-191. Doi: 10.1016/j. ecoenv.2017.08.032

FAOSTAT. 2016. Crops. In: http://www.fao.org/faostat/ en/\#data/QC; consulted: December, 2016.

Gomes, R.S.S., A.C.F. Demartelaere, L.C. Nascimento, W.O. Maciel, and D.B.N.S. Wanderley. 2016. Bioatividade de indutores de resistência no manejo da antracnose da goiabeira (Psidium guajava L.). Summa Phytopathol. 42(2), 149-154. Doi: 10.1590/0100-5405/2103

Gomes, E.C.S., R.P. Leite, F.J.A. Silva, L.S. Cavalcanti, L.C. Nascimento, and S.M. Silva. 2011. Manejo do míldio e ferrugem em videira com indutores de resistência: produtividade e qualidade pós-colheita. Trop. Plant Pathol. 36(5), 332-335.

Gomes, F.B., J.C. Moraes, C.D. Santos, and M.M. Goussain. 2005. Resistance induction in wheat plants by silicon and aphids. Sci. Agric. 62(6), 547-551. Doi: 10.1590/ S0103-90162005000600006

Gonçalves, V.G. 2009. Arquitetura de planta, teores de clorofila e produtividade de batata, CV. atlantic, sob doses de silicato de potássio via foliar. MSc thesis. Universidade Federal de Uberlândia, Uberlândia, Brazil.

Graham, J.H. and M.E. Myers. 2011. Soil application of SAR inducers imidacloprid, thiamethoxam, and acibenzolar-S-methyl for citrus canker control in young grapefruit trees. Plant Dis. 95(6), 725-728. Doi: 10.1094/ PDIS-09-10-0653

Heath, R.L. and L. Packer. 1968. Photoperoxidation in isolated chloroplasts: kinetics and stoichiometry of fatty acid peroxidation. Arch. Biochem. Biophys. 125(1), 189-198. Doi: 10.1016/0003-9861(68)90654-1

Hodson, M.J., P.J. White, A. Mead, and M.R. Broadley. 2005. Phylogenetic variation in the silicon composition of plants. Ann. Bot. 96(6), 1027-1046. Doi: 10.1093/aob/ mci255 
Hogan, M.E., I.E. Swift, and J. Cone. 1983. Urease assay and ammonia release from leaf tissues. Phytochem. 22(3), 663-667. Doi: 10.1016/S0031-9422(00)86958-7

Jiao, W., X. Li, X. Wang, J. Cao, and W. Jiang. 2018. Chlorogenic acid induces resistance against Penicillium expansum in peach fruit by activating the salicylic acid signaling pathway. Food Chem. 260, 274-282. Doi: 10.1016/j.foodchem.2018.04.010

Kar, M. and D. Mishra. 1976. Catalase, peroxidase and polyphenoloxidase activities during rice leaf senescence. Plant Physiol. 57(2), 315-319. Doi: 10.1104/ pp.57.2.315

Koca, H., M. Bor, F. Özdemir, and I. Türkan. 2007. The effect of salt stress on lipid peroxidation, antioxidative enzymes and proline content of sesame cultivars. Environ. Exp. Bot. 60(3), 344-351. Doi: 10.1016/j. envexpbot.2006.12.005

Lamichhane, J.R., W. Arendse, S. Dachdrodt-Saaydeh, P. Kudsk, J.C. Roman, J.E.M. Van Bijsterveldt-Gels, M. Wick, and A. Messéan. 2015. Challenges and opportunities for integrated pest management in Europe: a telling example of minor uses. Crop Prot. 74, 42-47. Doi: 10.1016/j.cropro.2015.04.005

Lawlor, D.W. 2002. Carbon and nitrogen assimilation in relation to yield: mechanisms are the key to understanding production systems. J. Exp. Bot. 53(370), 773 787. Doi: 10.1093/jexbot/53.370.773

Liang, Y., M. Nikolic, R. Bélanger, H. Gong, and A. Song. 2015. Silicon in agriculture. Springer, Dordrecht, The Netherlands. Doi: 10.1007/978-94-017-9978-2

Lima, E.S. and D.S.P. Abdalla. 2001. Peroxidação lipídica: mecanismos e avaliação em amostras biológicas. Rev. Bras. Ciênc. Pharm. 37(3), 293-303.

Lorencetti, G.A.T., S.M. Mazaro, M. Potrich, E.R. Lozano, L.R. Barbosa, D. Luckmann, and S. Dallacort. 2015. Produtos alternativos para controle de Thaumastocoris peregrinus e indução de resistência em plantas. Floresta Ambient. 22(4), 541-548. Doi: 10.1590/2179-8087.066913

Mandal, S. 2010. Induction of phenolics, lignin and key defense enzymes in eggplant (Solanum melongena L.) roots in response to elicitors. Afr. J. Biotechnol. 9(47), 8038-8047. Doi: 10.5897/AJB10.984

Mitani, N. and J.F. Ma. 2005. Uptake system of silicon in different plant species. J. Exp. Bot. 56(414), 1255-1261. Doi: $10.1093 / \mathrm{jxb} /$ eri121

Mittler, R. 2002. Oxidative stress, antioxidants and stress tolerance. Trends Plant Sci. 7(9), 405-410. Doi: 10.1016/S1360-1385(02)02312-9

Moya-Elizondo, E.A. and B.J. Jacobsen. 2016. Integrated management of Fusarium crown rot of wheat using fungicide seed treatment, cultivar resistance, and induction of systemic acquired resistance (SAR). Biol. Contr. 92, 153-163. Doi: 10.1016/j.biocontrol.2015.10.006
Mulder, E.G., R. Boxma, and W.L. Van Veen. 1959. The effect of molybdenum and nitrogen deficiencies on nitrate reduction in plant tissues. Plant Soil 10(4), 335355. Doi: 10.1007/BF01666209

Pereira, H.S., G.C. Vitti, and G.H. Korndörfer. 2003. Comportamento de diferentes fontes de silício no solo e na cultura do tomateiro. Rev. Bras. Ciênc. Solo 27(1), 101-108. Doi: 10.1590/S0100-06832003000100011

Ranganathan, S., V. Suvarchala, Y.B.R.D. Rajesh, M. Srinivasa-Prasad, A.P. Padmakumari, and S.R. Voleti. 2006. Effects of silicon sources on its deposition, chlorophyll content, and disease and pest resistance in rice. Biol. Plant. 50(4), 713-716. Doi: 10.1007/s10535-006-0113-2

Sangeetha, S. and D.V.L. Sarada. 2015. The phenyl derivative of Pyranocoumarin prevents Fusarium oxysporum f.sp. lycopersici infection in Lycopersicon esculentum via the induction of enzymes of the phenylpropanoid pathway. Appl. Biochem. Biotech. 175(2), 1168-1180. Doi: 10.1007/s12010-014-1285-4

Shah, J., R. Chaturvedi, Z. Chowdhury, B. Venables, and R.A. Petros. 2014. Signaling by small metabolites in systemic acquired resistance. Plant J. 79(4), 645-658. Doi: 10.1111/tpj.12464

Shah, J. and J. Zeier. 2013. Long-distance communication and signal amplification in systemic acquired resistance. Front. Plant Sci. 4, 30. Doi: 10.3389/fpls.2013.00030

Siddiqui, Y. and S. Meon. 2009. Effect of seed bacterization on plant growth response and induction of disease resistance in chilli. Agric. Sci. China 8(8), 963-971. Doi: 10.1016/S1671-2927(08)60301-6

Silva, J.M., R.S. Ferreira, A.S. Melo, J.F. Suassuna, A.F. Dutra, and J.P. Gomes. 2013. Cultivo do tomateiro em ambiente protegido sob diferentes taxas de reposição da evapotranspiração. Rev. Bras. Eng. Agríc. Ambient. 17(1), 40-46. Doi: 10.1590/S1415-43662013000100006

Stout, M.J., J. Workman, and S.S. Duffey. 1994. Differential induction of tomato foliar proteins by arthropod herbivores. J. Chem. Ecol. 20(10), 2575-2594. Doi: 10.1007/BF02036193

Taiz, L., E. Zeiger, I.M. Moller, and A. Murphy. 2016. Fisiologia e desenvolvimento vegetal. $6^{\text {th }}$ ed. Artmed, Porto Alegre, Brazil.

Teisseire, H. and V. Guy. 2000. Copper-induced changes in antioxidant enzymes activities in fronds of duckweed (Lemna minor). Plant Sci. 153(1), 65-72. Doi: 10.1016/ S0168-9452(99)00257-5

Teixeira, W.F., E.B. Fagan, L.H. Soares, R.C. Umburanas, K. Reichardt, and D.D. Neto. 2017. Foliar and seed application of amino acids affects the antioxidant metabolism of the soybean crop. Front. Plant Sci. 8, 327. Doi: 10.3389/fpls.2017.00327

Umesha, S. 2006. Phenylalanine ammonia lyase activity in tomato seedlings and its relationship to bacterial 
canker disease resistance. Phytoparasitica 34(1), 6871. Doi: 10.1007/BF02981341

Van Bruggen, A.H.C. and M.R. Finckh. 2016. Plant diseases and management approaches in organic farming systems. Annu. Rev. Phytopathol. 54, 25-54. Doi: 10.1146/annurev-phyto-080615-100123

Wang, S.Y. and G.J. Galleta. 1998. Foliar application and potassium silicate induces metabolic changes in strawberry plants. J. Plant Nutrit. 21(1), 157-167. Doi: 10.1080/01904169809365390
Xue, M. and H. Yi. 2017. Induction of disease resistance providing new insight into sulfur dioxide preservation in Vitis vinifera L. Sci. Hortic. 225, 567-573. Doi: 10.1016/j.scienta.2017.07.055

Zaidi, S.S.E.A., M.S. Mukhtar, and S. Mansoor. 2018. Genome editing: targeting susceptibility genes for plant disease resistance. Trends Biotechnol. 36, 898-906. 10.1016/j.tibtech.2018.04.005

Zhu, Y. and H. Gong. 2014. Beneficial effects of silicon on salt and drought tolerance in plants. Agron. Sustain. Dev. 34, 455-472. Doi: 10.1007/s13593-013-0194-1 